\title{
Evidence Gathering: The Exclusionary Rule in China
}

\author{
Victoria M. Time ${ }^{1}$ \\ ${ }^{1}$ Department of Sociology \& Criminal Justice, Old Dominion University, Norfolk, Virginia, USA \\ Correspondence: Victoria M. Time, Department of Sociology \& Criminal Justice, Old Dominion University, \\ Norfolk23529, Virginia, USA. Tel: 757-683-6100. E-mail: vtime@odu.edu
}

\author{
Received: September, 29, 2012 Accepted: October 15, 2012 Online Published: October 26, 2012 \\ doi:10.5539/ilr.v1n1p144 \\ URL: http://dx.doi.org/10.5539/ilr.v1n1p144
}

\begin{abstract}
Using a content analysis strategy, this paper argues against recent skepticism about China's newly revised "exclusionary rule" - a rule that requires evidence to be suppressed if police officers acquired it in violation of standard procedures. Some current studies like those of Lewis (2011) and Heon-Ju Rho (2011) have referred to China's exclusionary rule as "mere symbolism" and "window dressing." Based on studies which explain that it does take considerable time to evaluate the effectiveness of transplanted law, the argument of this paper favors the idea that hasty assessments of a newly passed law should be withheld until a reasonable volume of cases are examined. That is, there has to be sufficient data to assess whether the rule creates an impact positively, negatively, or if no change is envisaged.
\end{abstract}

This paper thus finds relevance in that (1) it lends support to the revised criminal procedure law that relates to the exclusionary rule adopted in China; (2) it highlights the merits of the spirit and intent of the exclusionary rule, and (3) it calls for restraint in early assessment of the law.

Keywords: China, the exclusionary rule, legal transplants, searches and seizures, evidence collection, exclusionary regulations, capital case regulations

\section{Introduction}

Hyeon-ju Rho (2011) wrote an insightful article in which she applauds Lewis' (2011) critique of the 2010 Rule of Evidence in China. Of much significance is her analysis of Lewis' inquiry as to whether the exclusionary rule as put forth in the 2010 Rule of Evidence may be "a mere symbolic integrity-enhancing device or, alternatively, actually gain traction and be applied widely in criminal cases." Hueon-ju Rho suggests that based primarily on the application of the 2010 rule, used on a case by case basis, there is no room for optimism.

Of notable interest to this research is the 2012 revision of the Criminal Procedure Rules adopted during China's yearly legislative session which in essence stipulates that evidence collected by police in violation of proper police procedure has to be suppressed in court.

It is to be reckoned that the exclusionary rule is intended to put limitations and restraints on how police officers obtain evidence by not arbitrarily violating citizens' rights. Indeed the prohibition of unreasonable searches and seizures by police officers as the Chinese legislation intends is to promote human rights. How police officers are suppose to do their jobs is emphasized during training; just what type of criminals they will encounter, and how those encounters will transpire cannot for the most part be pre-determined. While the exclusionary rule is "rights-based" in that it is intended to deter police officers from encroaching on people's rights, only such rights as violated by police officers can result in the exclusion of evidence. It follows that when presumed violations of rights occur which are not of the doing of law enforcement officers, or which an initial law enforcement violation has been attenuated by the defendant's own actions, or by an independent source, any evidence in dispute may still be used against the defendant. This paper amplifies the merits of the exclusionary rule; it advocates bridling any early conclusions about the law in China; and it sheds light on some difficulties entailed in adopting foreign laws.

\section{Support for China's Exclusionary Rule}

The exclusionary rule has received much attention in the literature (Jones, 2012; Campbell, 2011; Thaman, 2011; Chen, 2011; Hyeon-ju, 2011). Without a search whose legality has been challenged there will be no basis to evoke the exclusionary rule. The balance between people's rights and police procedure is found in legislative 
enactments. In the United States, the IV Amendment sets forth procedures necessary for a valid search. Officers must have facts that a magistrate deems constitute probable cause for which the issuance of a warrant will be in order. Absent a warrant, and without exceptions to the warrant requirement recognized by courts such as consent to search, exigency, hot pursuit, plain view, etcetera, a person who was searched may challenge the legality of such a search. Remedies for breaches of legislative rights as for instance the IV Amendment right against unreasonable searches and seizures are embedded in judicial rulings.

In China, the Supreme People's Court laid ground works for the exclusionary rule which are subject to judicial interpretation. As Chen (2011, p. 231) indicates, two main legislations govern the exclusionary rule. These legislations include: (1) The Exclusionary Regulations - which put forth guidelines for exclusion of evidence (2) The Capital Case Regulations-- examines rulings relating to evidence in capital cases. Chen further explains that evidence may be excluded following a procurator's discretion and upon the defense's motion for such action to take place. Should the procurator be in disagreement with a court's ruling to exclude evidence, the onus then rests with the procurator to show through "clear facts and reliable, sufficient evidence" (Chen, p. 231), why such evidence should be used against the defendant.

Chen (2011) also makes the point that enacting laws and regulations is one thing, enforcing them is another, and that those charged with the duties of enforcing the laws play an integral role in the success of the exclusionary rule in China. Further, as he asserts giving that this rule is a derivative of western jurisprudence, it is uncertain how this will work out in China.

Hyeon-ju Rho (2011) is more obvious in her skepticism of China's exclusionary rule. Her worries focus on whether the rule is merely a show of good face or whether it is indeed a safeguard of people's rights. Giving that the 2012 revised criminal procedure rules of China reiterate the exclusionary rule, this author argues that restraint be exercised in passing judgment about the efficacy of the rule because the rule itself may not be the problem, and those vested with powers to enforce it have to get acclimated to its mandates. Further, even in the United States where the rule has been in existence for over a century, it still has problems as legal analyzes reveal (see Campbell, 2011; Scharf, 2010; Dickey, 2010). Following Horowitz's (1977) reasoning, Zalman (2008, p. 99) explains that the efficacy of the exclusionary rule can be assessed only when researchers inquire into whether or not "the number and rates of violations increased, decreased, or remained level...."

\section{What is the Exclusionary Rule Designed to Do?}

As China strives to shake off accusations of human rights violations, it is necessary that it takes steps to promulgate laws that secure the rights of citizens. When the drafters of the United States Constitution included the IVth Amendment, no safeguards were put in place. Even though the Fourth Amendment was ratified in 1791, it was not until the early cases of Boyd v. U.S. (1886), and Weeks v. U.S. (1914), that remedies for sloppy police work were put forth. While these were federal cases, it was in Mapp v. Ohio (1961) when harmony in the application of the remedies of Fourth Amendment of both federal and state cases was established.

The premise of the exclusionary rule is to deter police work that deviates from standard procedure, but not to repair it (see Campbell 2011). The rule is calculated to be a preventative mechanism against overzealous and arbitrary law enforcement. The effect of this rule is to put restraints on how law enforcement officers exercise power and authority in the execution of their jobs regardless of whether the law enforcement encounter is with one accused of a crime or one merely under suspicions of illegal conduct. In essence, the rule's primary purpose is to have a deterrent effect against unlawful law enforcement practices, and only have its secondary effect to advance the objective of preserving the soundness of the legal system. In order to sustain "the rights of the guilty and the innocent alike, and to enable the judiciary to avoid the taint of partnership in official lawlessness" courts should uphold the exclusionary rule (Campbell, 2011, p. 389). Not only should the illegally seized evidence be excluded, but any derivative (fruits of the poisonous tree) should be suppressed as well.

While the exclusionary rule in the U.S. is mainly designed to address Fourth Amendment violations, when the right against self incrimination (Vth Amendment) is violated through coercive interrogation, a confession is excluded in court. In China as Chen (2011, p. 233) explains, "where the Exclusionary Regulations effectively establish different exclusionary rules for illegally obtained oral and physical evidence, the Capital Case Regulations establish new rules of mandatory exclusion for both illegally obtained oral and physical evidence." The exclusionary rule relating to searches and seizures thus conflates with illegally obtained confessions. In China, the need to suppress evidence or confessions that are illegally extracted through torture or other coercive practices is mandated by the laws of Criminal Procedure as well as by international conventions that forbid torture and human degradation (Chen, 2011). See the ruling in Rochin v. California (1952) in the United States. For violations that are not deemed to be egregious in China which Chen classes as "minor "procedural blemish" 
(such as failure to include signatures on documents) discretion is used whether or not to suppress any evidence. In this regard, the court has to introduce remedial solutions. The procurator may either order that the evidence be obtained again, or in the event that the evidence cannot be obtained a second time, the prosecutor has the task to adduce a palpable explanation for why the violation occurred (Chen, 2011).

While one may find it odd that a procurator in China has discretion to exclude or include evidence, one has to realize that this same process happens in the United States. Courts in the United States now and then include evidence when they can establish that the officer acted in good faith, that is, they may decide not to exclude evidence if they deem that the officer acted with the reasonable and honest belief that the officer was acting in pursuance of the law, even though it transpires that somehow an error was detected (see Leon v. U.S. (1984); Massachusetts $v$. Shepherd (1984). Each decision relating to the good faith exception is determined only by an officer of the court, "a statute, or official records" (see Zalman, 2008, p. 81).

As well, in the United States, evidence that is derived based on information provided by an independent informant (the independent source exception) may be used to convict a defendant as long as that independent tipster was unconnected to an initial police illegal entry or search of the defendant's premises (see Segura v. U.S. (1984)). Further, if it was inevitable that the evidence obtained by police through illegal means would have been found regardless of the illegal procedure of the police (the inevitable discovery exception), courts generally may use the evidence (see Nix v. William (1984)). Also, evidence that is obtained through an illegal means may be used in court if somehow by the defendant's own doing he weakens the link between the police illegality and his wrong doing (the attenuation/purged taint exception) to the extent that the courts approve the use of evidence that otherwise would have been suppressed (see Wong Sun v. United States (1963))

\section{Why Restraint Should be Exercised in Making Hasty Assessments of the Exclusionary Rule in China.}

Hyeon-ju Rhu's skepticism of the 2010 exclusionary rule in China which is reiterated in the proposed 2012 revision of the rule is a reflection of Lewis' (2011). Some of the concerns raised by the duo are that, the National Human Rights Action Plan of 2009 in China does not give good guidance in regards to how proper interrogations should be conducted so as to avoid coerced confessions; and that because the section addressing the rights of detainees was issued prior to the 2010 Evidence Rules, it is more of window dressing. As well, they raise concerns about the massive powers that police officers in China have especially since there is no buffer as for example, a magistrate/judge who determines probable cause before issuing warrants as is the case in the United States. Lewis also cites disenchantment of the public to what goes on in China relating to rights violations, and further asserts that China has ratified the United Nations Convention Against Torture and Cruel Inhumane or Degrading Treatment or Punishment (CAT), but not the International Covenant on Civil and Political Rights (ICCPR). She claims that international pressure motivated China to adopt the Evidence Rules of 2010. Further, Lewis discusses the problems evident in measuring deterrence and makes the point that "In China, the concern is not that the government will become a lawbreaker, rather, that the government already is a lawbreaker" (Lewis, 2011, p. 41). Lewis also raises the point that many defendants in China act pro se, that is, they self-represent. Without legal knowledge, a defendant may not know when to challenge government's actions. Two other challenges face China in regards to the exclusionary rule according to Lewis. She lists "weak courts" and judges who "avoid exercising the power that they do have" (2011, p. 45). To her credit, Lewis is detailed in her analyzes and enumeration of loopholes and documented violations of people's rights in China.

Despite the problems Lewis and Hyeon-ju Rhu raise and the skepticism that they display, they both nonetheless leave room for optimism. Lewis acknowledges "it is too early to tell whether the 2010 Evidence Rule will remain a mere gloss to enhance the PRC Government's public support or whether tangible changes will take root under the veneer" (2011, p. 49).

Hyeon-ju Rhu is right in explaining that impact of the rule should not only be determined by how it is applied in specific cases, because as in the case of China it may not provide room for optimism. But then, she explains the progress in the use of the rule in Yancheng City in Jiangsu Province. Following such criticisms leveled on China, the legislators seem to be in a precarious state- damn if they legislate "rights based laws," damn if they don't. Baby steps have to be taken for progress to become obvious, a point Lewis concedes, and concludes that even though chips may be taken away from the rigor of the exclusionary rule, the rule is still the dominant way by which people's rights are secured. Hyeon-ju Rhu highlights the many obstacles raised by Lewis that may likely impede the effectiveness of the exclusionary rule in China; but goes on to explain what is being done to curb any misuse or misapplication of the rule. Among the steps being taken in China, Hyeon-ju Rhu discusses the use of cameras to record interrogations, the 2010 Evidence Rules and the Trial Opinion on Several Issues Regarding Standardizing Sentencing Procedure (2010) by the Supreme People's Court (SPC), Ministry of Public Security 
(MPS), Ministry of Justice, and Ministry of State Security, which support the presence of counsel for suspects and defendants through the criminal justice process (Hyeon-ju Rhu, 2011, p. 734).

Among the many issues relating to the exclusionary rule that Chen discusses, he thoughtfully makes the point that "laws alone do not implement themselves" (p. 241) and that whether rules:

can indeed be implemented, and in particular whether they can realize the goals of legal reformers - whether they can help resolve the problems of torture, unlawful gathering of evidence, the reduction of criminal procedure to mere formality, the refusal of investigating personnel to testify at trial - are questions awaiting empirical inquiry and theoretical reflection (p. 241).

Legrand (1997) has warned that doctrines/laws that are rooted from other systems sometimes detract from their original intent when introduced to a new system, as a consequence, he warns that prudence should be exercised in what laws to borrow and how much is expected with regard to success. Blum (2008, p. 2151) endorses Legrand's premise after examining the exclusionary rule's application in Israel, as he maintains that "broader cultural and historical factors have affected [the] application of the exclusionary rule and the goals it seeks to achieve." China's politics, system of justice, and culture is fundamentally different from what obtains in the United States, and a doctrine or rule that is essentially American/English which has had a very short existence in China, cannot be expected to be quite effective overnight.

In his book, Legal Accents, Legal Borrowing..., Nolan (2009), advances the theme that culture plays an integral role in the application of borrowed laws, and that without adjustments in the law to suit the realities of an environment, law enforcers and the community they serve are likely to embroil in a chain of events that are diametrically different from what the transplanted law was designed to do.

Singel (2005-2006), for instance, while concentrating on effects of federal and state laws transplanted on tribal laws, delved into explaining why developing countries thought that transplanting western laws will help in their development and modernization, but how the grim reality that " transplanting western laws was not a panacea for developing countries" quickly became evident (p. 364).

Fitch (2011) opines that regardless of how hard police departments try to prevent police misconduct by recruiting those who exhibit healthy moral values, and provide sound training to them, they still cannot prevent abuse of power by some officers. He states that "mitigating the risk for officer misconduct requires a more complete understanding of human behavior and motivation" p. 19. He goes on to offer the following guidelines to limit police misconduct: "reward appropriate conduct and correct inappropriate behavior;" "frequently discuss ethics in the work place;" engage officers in case studies that provide "real-world examples that challenge officers to think critically;" police departments "must closely examine their policies, reward systems, and training to ensure that their agency fosters a culture of firm ethical values" p. 23. Hyeon-ju Rhu and Lewis provide accounts of police misconduct in China, perhaps over time they will trickle down.

As well, the judiciary in China as elsewhere is not immune from criticism. Chen (2011) as discussed above reminds us that personnel help implement laws because laws do not implement themselves. Wu (2011) explains revisions made to the Basic Principles of the Professional Ethics of Judges by the Supreme People's Court of China. That these steps are being taken is suggestive of progress.

\section{Conclusion}

This study is not intended to examine China's exclusionary rule. It simply advocates restraint in making hasty judgments or assumptions about the rule. Like any new rule or law anywhere, it takes time for people to be acculturated to it. Whether or not a new or revised law is effective, or as Hyeon-ju Rho states a "mere symbolism" or "wide application," cannot be assessed in one to two years. Programs and laws are best evaluated over time. Sporadic and isolated examples of strengths or weaknesses cannot provide an accurate picture of the effectiveness or ineffectiveness of a program.

Too much criticism or skepticism about its success should not be levied too soon to the extent of precluding the positives that the rule is designed to advance. The exclusionary rule by itself is not the panacea for rights violations. As Zalman (2008) notes, civil law suits, injunctions, and even criminal law suits for blatant police violations are "true remedies." In using the expression 'legal irritants' Teuber (1998) alludes to the phenomenon whereby transplanted laws initially do not automatically supplant how prevalent legal terms and practices are construed. The road to a more robust use and positive application of the rule in China may take time. The fact that China once more made revisions in 2012 to its criminal procedures suggests that they cherish and respect human rights. 


\section{References}

Blum, B. (2008). Doctrines without borders: The "New" Isreali exclusionary rule and the dangers of legal transplantation. Stanford Law Review, 60, 2131-2171.

Campbell, C. (2011). Davis v. United States: Why the Supreme Court should preserve judicial integrity and prevent further erosion of the exclusionary rule. Faulkner Law Review, 2(2), 361-389.

Chen, R. (2011). China's new exclusionary rule: An introduction. Columbia Journal of Asian Law, 24(2), 229-246.

Dickey, M. (2010). ADR gone wild: Is it time for a federal mediation exclusionary rule? Ohio State Journal on Dispute Resolution, 25(3), 713-778.

Fitch, B. (2011). Rethinking ethics in law enforcement. FBI Law Bulletin, 80(10), 18-24.

Hyeon-ju, R. (2011). The exclusionary rule in China and a closer look at the dynamics of reform. New York University Journal of International Law and Politics, 43(3), 729-738.

Jones, D. (2012). Hudson v. Michigan and the decline of the exclusionary rule. Police Practice and Research, 13(3), 282-293. http://dx.doi.org/10.1080/15614263.2011.627740

Legrand, P. (1997). The impossibility of legal transplants. Maastricht Journal of European and Comparative Law, 4, 111-124.

Lewis, M. (2011). Controlling abuse to maintain control: The exclusionary rule in China. New York University Journal of International Law and Politics, 43(3), 1-48.

Nolan, J. (2009). Legal Accents, Legal Borrowing: The International Problem-Solving Court Movement. Princeton, N.J.: Princeton University Press.

Scharf, I. (2010). The exclusionary rule in immigration proceedings: Where it was, where it is, where it may be going. San Diego International Law Journal, 12(1), 53-88.

Singel, W. (2006). Cultural sovereignty and transplanted law: Tensions in indigenous self-rule. Kansas Journal of Law \& Public Policy, 15, 357-368.

Teubner, G. (1998). Legal Irritants: Good faith in British Law or how unifying law ends up in new divergences. Modern Law Review, 61(1), 11-12. http://dx.doi.org/10.1111/1468-2230.00125

Thaman, S. (2011). Constitutional rights in the balance: Modern exclusionary rules and the toleration of police lawlessness in the search for truth. University of Toronto Law Journal, 61(4), 691-735. http://dx.doi.org/10.3138/utlj.61.4.691

$\mathrm{Wu}$, R. (2011). Strengthening judicial ethics in China - The new principles and regulation: Correspondent's report from China. Legal Ethics, 14(1), 135-137. http://dx.doi.org/10.5235/146072811796372961

Zalman, M. (2008). Criminal Procedure: Constitution and Society (5th ed.). Upper Saddle River, New Jersey: Pearson/Prentice Hall.

\section{Cases}

Boyd v. U.S., 116 U.S. 616 (1886).

Mapp v. Ohio, 367 U.S. 643 (1961).

Massachusetts v. Shepherd, 468 U.S. 981 (1984).

Nix v. Williams, 467 U.S. 431 (1984).

Rochin v. California, 342 U.S. 165 (1952).

Segura v. U.S., 468 U.S. 796 (1984).

U.S. v. Leon, 468 U.S. 897 (1984).

Weeks v. U.S., 232 U.S. 383 (1914).

Wong Sun v. U.S., 371 U.S. 471 (1963). 